Article

\title{
Effects of Climate Change and LUCC on Terrestrial Biomass in the Lower Heihe River Basin during 2001-2010
}

\author{
Haiming Yan ${ }^{1,+}$, Jinyan Zhan ${ }^{1, *,+}$, Feng $\mathrm{Wu}^{2,3}$ and Huicai Yang ${ }^{4}$ \\ 1 State Key Laboratory of Water Environment Simulation, School of Environment, Beijing Normal University, \\ Beijing 100875, China; yanhm.dls@gmail.com \\ 2 Institute of Geographic Sciences and Natural Resources Research, Chinese Academy of Sciences, \\ Beijing 100101, China; wufeng@igsnrr.ac.cn \\ 3 Center for Chinese Agricultural Policy, Chinese Academy of Sciences, Beijing 100101, China \\ 4 College of Water Sciences, Beijing Normal University, Beijing 100875, China; colourful-yhc@163.com \\ * Correspondence: zhanjy@bnu.edu.cn; Tel.: +86-10-6483-3471 \\ + These authors contributed equally to this work.
}

Academic Editors: Xiangzheng Deng and Tapas Mallick

Received: 31 December 2015; Accepted: 8 March 2016; Published: 1 April 2016

\begin{abstract}
Ecosystem services are tightly coupled with availability of solar energy and its partition into energy fluxes, and biomass accumulation, which represents the energy flux in ecosystems, is a key aspect of ecosystem services. This study analyzed the effects of climate change and land use and land cover change (LUCC) on the biomass accumulation change in the Lower Heihe River Basin during 2001-2010. Biomass accumulation was represented with net primary productivity (NPP), which was estimated with the C-Fix model, and scenario analysis was carried out to investigate effects of climate change and LUCC on biomass accumulation change in a spatially explicit way. Results suggested climate change had an overall positive effect on biomass accumulation, mainly owning to changes in $\mathrm{CO}_{2}$ concentration and temperature. LUCC accounted for $70.61 \%$ of biomass accumulation change, but primarily owning to fractional vegetation change (FVCC) rather than land conversion, and there is a negative interactive effect of FVCC and climate change on biomass accumulation, indicating FVCC resulting from water diversion played a dominant in influencing biomass accumulation. These results can provide valuable decision support information for the local ecosystem managers and decision makers to guarantee sustainable provision of essential ecosystem services.
\end{abstract}

Keywords: biomass accumulation; water diversion; climate change; energy flux; fractional vegetation change (FVCC); net primary productivity (NPP)

\section{Introduction}

Ecosystem services are tightly coupled with the availability of solar energy and its partition into energy fluxes in the heterogeneous landscape, which was dominated by heat dissipation on the expense of photosynthesis [1-6]. About $3.8 \times 10^{24} \mathrm{~J}$ solar energy is annually absorbed by the surface and atmosphere of the Earth, $95.5 \%$ of which dissipates as the sensible and latent heat fluxes, only $4.5 \%$ is channeled into photosynthesis [6,7]. The photosynthesis using the photosynthetically active radiation (PAR) as the energy source is the only process by which carbon dioxide $\left(\mathrm{CO}_{2}\right)$ is converted into organic carbon and the solar energy is converted into chemical energy and stored as biomass [6,8]. Once stored, the biomass can provide food for heterotrophic organisms and can be processed into usable energy such as renewable fuel or bioenergy, which has currently attracted great interest in the global energy scenario [6,9-14]. Biomass is the total mass (or energy) of all living material (Units: $\mathrm{gC} \cdot \mathrm{m}^{-2}$ or $\mathrm{kJ} \cdot \mathrm{m}^{-2}$ ), where the energy and (reduced) carbon can be used interchangeably 
(39 kJ per gC) $[9,10]$. The biomass accumulation is a key aspect of ecosystem services since it represents the energy available for upper trophic levels and strongly influences the dynamics of atmospheric $\mathrm{CO}_{2}$, and understanding the processes that affect biomass accumulation is also critical for planning strategies to mitigate the accumulation of $\mathrm{CO}_{2}$ in the atmosphere [11,12]. In particular, the economic success of agricultural and forestry systems, which harvest solar radiation to produce food and fiber through biomass accumulation, also requires proper management for the capture and partition of solar radiation $[15,16]$. The partition of energy results from the long-term interactions between biogeochemical cycling, climatic factors and disturbance as well as the short-term interactions between plant physiology and atmospheric boundary layers [7], and it is important to analyze where energy is lost and carry out integrated measurements of atmosphere-ecosystem exchange to find ways of improving the biomass accumulation in ecosystems [13].

Climate change and land use and land cover change (LUCC) are primary driving forces for biomass accumulation in terrestrial ecosystems [17-20], and assessing their relative contribution to biomass accumulation change is critical for finding ways of guaranteeing provision of ecosystem services and planning strategies to mitigate the accumulation of $\mathrm{CO}_{2}$ in the atmosphere [15]. Climate change and LUCC can influence the biomass accumulation of vegetation through influencing the fraction of radiation intercepted, radiation use efficiency and harvest index [12,21-23], and they can also lead to the shifts in the overall structure and function of ecosystems and consequently influence partition of energy fluxes and ecosystem energy balance and result in changes in biomass [24]. Net primary productivity (NPP) measures the transfer of energy to the biosphere and terrestrial $\mathrm{CO}_{2}$ assimilation $[9,25]$. NPP can be used to represent biomass accumulation and provides a set of indicators for measuring effects of climate change and LUCC on biomass accumulation and trophic energy fluxes in natural ecosystems and managed lands [9,25-27]. Besides, There have been a number of models for estimating NPP in large areas, which can be categorized into statistical (climate-related) models, light use efficiency (LUE) models and process-based models [28,29]. Among all these models, LUE models have the highest potential to accurately reflect the spatiotemporal dynamics of NPP due to the simplicity of their concepts and the high availability of remote sensing data [11], and various LUE models have been developed (e.g., CASA, C-Fix) [30,31]. In addition, the effects climate change and LUCC on biomass accumulation have been generally analyzed with statistical methods or scenario analysis [32-34]. However, the statistical methods cannot reflect the effects of influencing factors on biomass accumulation in a spatially explicit way [26,34-37]. By contrast, scenario analysis with process-based terrestrial ecosystem models can reflect the effects of influencing factors on biomass accumulation in a spatially explicit way and is often proposed as a simple, rapid and sensitive method to study effects of environmental changes on the photosynthesis and biomass accumulation $[5,38,39]$. However, current research with scenario analysis has generally focused on influence of climate change and land conversion (LC), with little attention paid to the fractional vegetation cover change (FVCC) which may have more important influence on biomass accumulation at microscopic scales [15,17,40-42].

The arid and semi-arid regions plays an important role in providing various ecosystem services and guaranteeing human well-beings, but the vegetation dynamics and biomass accumulation in these regions are very sensitive to various disturbances due to severe lack of water resources [1-3,43-45]. What is worse, climate change and human activities have further aggravated the drought stress that reduces the biomass accumulation of vegetation in these regions [34,46-50]. The rational water allocation has been considered as the fundamental method to solve problems resulting from water scarcity [48,51-53], for example, the Chinese government implemented the Ecological Water Diversion Project in 2000 to address the severe ecological degradation in the Heihe River Basin, the second largest inland river basin in Northwest China [28,54]. However, much remains unknown about the impacts of water diversion and other influencing factors on ecosystem services in this region [34,55-58]. To better understand the response of biomass accumulation to its influencing factors in this region, this study analyzed the effects of climate change and LUCC on biomass accumulation in the Lower Heihe River 
Basin during 2001-2010. Biomass accumulation was represented with NPP, which was estimated the C-Fix model. The effects of climate change and LUCC on the biomass accumulation were investigated through the scenario analysis in a spatially explicit way, and maps of the biomass accumulation change under different scenarios were produced, which are very useful to the local ecosystem managers and decision makers. Specific objectives of this study were: (1) to examine the spatiotemporal variation in biomass accumulation during 2001-2010; and (2) to elucidate the contribution of climate change and LUCC to change in biomass accumulation during the study period.

\section{Materials and Methods}

\subsection{Study Area}

The Lower Heihe River Basin lies between $97.13^{\circ} \mathrm{E}$ and $103.12^{\circ} \mathrm{E}$ and $39.87^{\circ}-42.79^{\circ} \mathrm{N}$, with the total land area of approximately $7.71 \times 10^{4} \mathrm{~km}^{2}$, covering Jinta County in Gansu Province and Ejina Banner in Inner Mongolia and accounting for approximately $60 \%$ of the total land area of the Heihe River Basin (Figure 1). There is a temperate continental climate characterized by extremely serious moisture deficiency and water shortage in this region, where the air temperature fluctuates between -37.1 and $44.5{ }^{\circ} \mathrm{C}$ and the annual average precipitation is generally below $50 \mathrm{~mm}$ [59]. With the altitude of 869-1885 m, there are mainly plains in the Lower Heihe River Basin. Most part of this region is covered by unused land such as sandy land and Gobi, which accounted for approximately $83.02 \%$ of the total land area of the study area in 2010 , while the grassland accounted for only $14.76 \%$. There is mainly gray-brown desert soil and gray desert soil in this region, making this region very susceptible to wind erosion. However, there is one of the largest original Populus euphratica forests of the world in this region, which serves as a key ecological barrier to intercept the sandstorms into China and plays a key role in guaranteeing the ecological safety of Northern China. In the Lower Heihe River Basin, the local vegetation heavily depends on the surface water and groundwater replenished by runoff of the Heihe River, but unfortunately vegetation cover has degraded seriously during past decades, leading to serious decline of key ecosystem services, e.g., biomass accumulation and soil conservation [34]. To restore the ecological environment in the Lower Heihe River Basin, the Ecological Water Diversion Project was implemented in 2000, which led to remarkable changes in vegetation cover and efficiency of PAR interception and absorption, causing great concerns about uncertainties in provision of ecosystem services under different water resource management conditions [54].

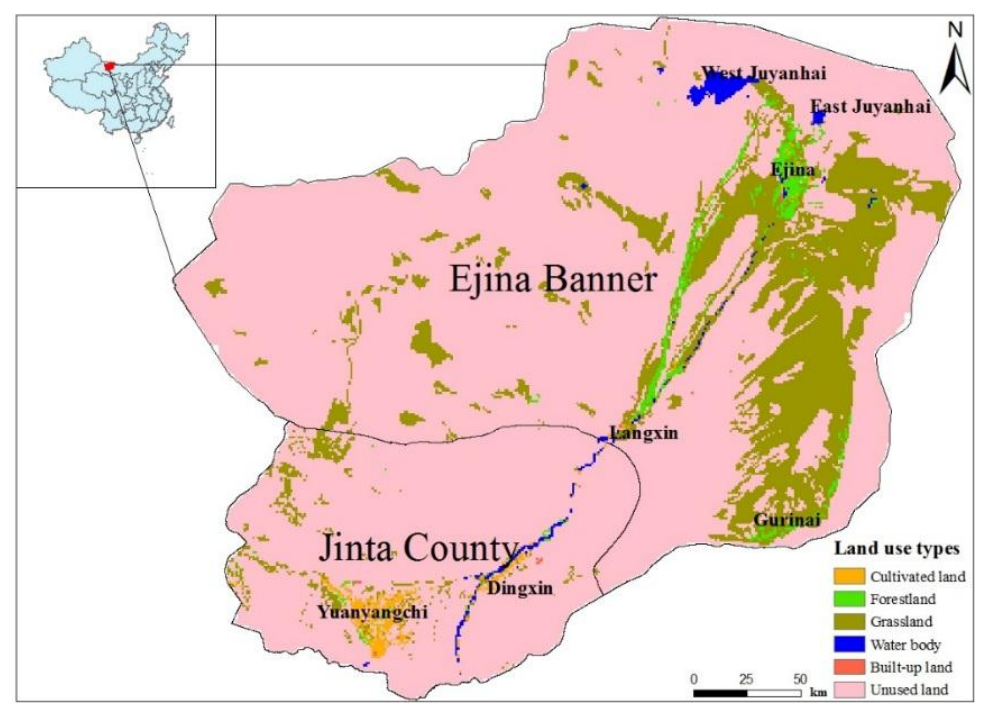

Figure 1. Location of the Lower Heihe River Basin and land use in 2010. 


\subsection{C-Fix Model}

The biomass accumulation was represented with NPP estimated with the C-Fix model, a widely used LUE model that has been successfully used in Europe, Africa and China [56,60]. The C-Fix model quantifies NPP as a function of absorbed photosynthetically active radiation (APAR) and biome-specific or plant functional group-specific light use efficiency based on $\mathrm{CO}_{2}$ concentration, temperature, solar radiation and fraction of absorbed photosynthetically active radiation ( $f A P A R)$ as follows.

$$
N P P_{d}=\left[p_{\left(T_{a t m}\right)} \times C_{2} f e r t \times \varepsilon \times f A P A R \times c \times S_{g . d}\right] \times\left(1-A_{d}\right)
$$

where $\mathrm{NPP}_{d}$ is the daily NPP (Unit: $\mathrm{gC} \mathrm{m}^{-2}$ ), $p_{(\mathrm{Tatm})}$ is the normalized temperature dependency factor ranging between 0 and $1, \mathrm{CO}_{2}$ fert is the normalized $\mathrm{CO}_{2}$ fertilization factor, $\varepsilon$ is the radiation use efficiency (Unit: $\mathrm{gC} / \mathrm{MJ}$ ), fAPAR is the fraction of Absorbed Photosynthetically Active Radiation, $c$ the climatic efficiency giving the ratio of PAR to global radiation; $S_{g, d}$ is the daily incoming global solar radiation (Unit: MJ. $\mathrm{m}^{-2} \cdot \mathrm{d}^{-1}$ ); and $A_{d}$ is defined as an autotrophic respiratory fraction of gross primary productivity. More specific explanations can be found in the literature $[56,60]$.

\subsection{Data and Parameters}

A database for estimating biomass accumulation was built, including the climate data, land use data, digital elevation model (DEM), Normalized Difference Vegetation Index (NDVI) data, and $\mathrm{CO}_{2}$ concentration during 2000-2010. The climate data including the air temperature and solar radiation were derived from daily records of meteorological stations within the study area and neighboring regions, and were interpolated into $1 \mathrm{~km}$ resolution grid data using gradient plus inverse distance squares method [61,62]. In particular, the daily temperature data were adjusted with the $1 \mathrm{~km}$ resolution DEM data and monthly temperature lapse rates provided by the Heihe Plan Science Data Center [63]. The monthly $\mathrm{CO}_{2}$ concentration data during 2000 and 2010 were downloaded from the NOAA website [64]. The climate-related parameters were prepared as follows. First, the normalized temperature dependency factor $p_{(\mathrm{Tatm})}$ was calculated with the method described by Wang et al. [65]. Besides, the normalized $\mathrm{CO}_{2}$ fertilization factor $\left(\mathrm{CO}_{2}\right.$ fert $)$ was estimated with the daily air temperature and monthly $\mathrm{CO}_{2}$ concentration [60]. In addition, $c$ was set to be 0.48 as it is in the original C-Fix model. What is more, the grid data of $S_{g, d}$ were prepared with the daily meteorological observation data. Moreover, $A_{d}$ was estimated with the parameterization method of Goward and Dye, i.e., $A_{d}=\left(7.825+1.145 \times T_{a}\right) / 100$, where $T_{a}$ is the air temperature (Unit: $\left.{ }^{\circ} \mathrm{C}\right)$ [66].

The $1 \mathrm{~km}$ resolution land use data were derived from Landsat Thematic Mapper (TM)/Enhanced Thematic Mapper (ETM) images in 2000, 2005, 2008 and 2010, which was interpreted by Chinese Academy of Sciences, with the overall interpretation accuracy of $92.7 \%[61,62,67]$. There are six major land use types and 25 subclass land use types, which were reclassified in this study, and then parameters related to land use types were prepared as follows. The radiation use efficiency $\varepsilon$ was treated as a constant (i.e., $1.1 \mathrm{gC} / \mathrm{MJ}$ ) for all vegetation types in the original C-Fix model, but more and more studies have indicated that there is great difference of $\varepsilon$ among biomes due to the variations of vegetation structure and biochemical composition [17,60,68,69], and in this study the values of $\varepsilon$ for major vegetation types were assigned with the parameter values of Running et al. [68], which have been widely used in the estimation of NPP at global and regional scales (Table 1). Moreover, the NDVI data were derived from the cloud-free NDVI data from 2001 to 2011 in the Heihe River Basin [70], and FAPAR was calculated as a linear function of the NDVI [71] as follows.

$$
F_{A P A R_{N D V I}}=\frac{\left(N D V I_{(x, t)}-N D V I_{i, \text { min }}\right) \times\left(F A P A R_{\text {max }}-F A P A R_{\text {min }}\right)}{\left(N D V I_{i, \text { max }}-N D V I_{i, \text { min }}\right)}+F A P A R_{\text {min }}
$$

where $F A P A R_{\min }$ and $F A P A R_{\max }$ are 0.001 and 0.95 , respectively, regardless of the vegetation types [69]; $N D V I_{(x, t)}$ is the NDVI value in the $x^{\text {th }}$ pixel on the $t^{\text {th }}$ day, and the range of $t$ was between 110-310 
according to previous research, which represents the length of the growing season [72]; and $N D V I_{i, \max }$ and $N D V I_{i, \min }$ are threshold values of NDVI for full-vegetation and non-vegetation pixels for the $i^{\text {th }}$ vegetation type (Table 1), respectively, the values of which were determined according to the in situ measurements and the literature $[69,73,74]$.

Table 1. Parameter values of $N D V I_{i, \max }, N D V I_{i, \min }$ and $\varepsilon$ for major vegetation types. $N D V I_{i, \max }$ and $N D V I_{i, \min }$ refer to the threshold values of NDVI for full-vegetation and non-vegetation pixels for the $i^{\text {th }}$ vegetation type, respectively, and $\varepsilon$ is the radiation use efficiency.

\begin{tabular}{cccc}
\hline Land Use Type & NDVI $_{i, \max }$ & NDVI $_{i, \min }$ & $\varepsilon$ (Unit: gC/MJ) \\
\hline Cultivated land & 0.8474 & 0.0298 & 0.6040 \\
Grassland & 0.8474 & 0.0298 & 0.6080 \\
Closed forest & 0.5586 & 0.0298 & 1.0440 \\
Shrub & 0.6360 & 0.0298 & 0.7680 \\
Open forest & 0.6360 & 0.0298 & 1.0440 \\
Other forest & 0.6360 & 0.0298 & 1.0440 \\
\hline
\end{tabular}

\subsection{Scenario Development}

Accurately quantifying the effects of different drivers on terrestrial biomass accumulation requires an understanding of the controlling physiological and ecological processes of biomass accumulation [20]. The climate change is a primary driving force for terrestrial ecosystem productivity [17-19], and the effects of climate change on biomass accumulation can be reflected with different scenarios with changes of climatic factors [75]. Besides, the human activities can be categorized into explicit and implicit LUCC, i.e., LC due to internal human activities and FVCC due to the water diversion since water diversion has great influence on the water availability and subsequently the fractional vegetation cover in the study area $[47,54,74]$. The effects of LC on biomass accumulation can be reflected with scenarios with different land use data, while the effects of FVCC on biomass accumulation can be reflected with scenarios with different $f A P A R$ data since the fractional vegetation cover is linearly related with $f A P A R$. In addition, the simulation period was set to be 2001-2010 in this study since the Ecological Water Diversion Project was implemented in 2000. Moreover, the total of annual biomass accumulation during 2001-2010 were further summarized since major carbon and energy fluxes between the atmosphere and terrestrial biosphere are often expressed in terms of net biomass accumulation from annual NPP and the effects of some influencing factors on biomass accumulation are expected to be lagged as vegetation shows inertial dynamics associated to its dependence on water resources and soil characteristics [12,47,54,72,76].

Multiple scenarios were designed to study effects of climate change and LUCC on biomass accumulation in the study area after the performance of the C-Fix model was assessed by comparing with results in the literature since there are not adequate in situ measurement data. Three groups of scenarios were designed, i.e., Group I for LUCC only, Group II for climate change only, and Group III for both climate change and LUCC, which were further divided into 10 scenarios (Table 2). Specifically, Group I was used to analyze the effects of LUCC (including LC due to the internal human activities of the study area and FAPAR representing FVCC due to the water diversion) on biomass accumulation, in which Scenario L1 involved only LC and Scenario L2 involved both LC and FVCC while all climatic factors remained in 2001. 
Table 2. Scenarios for analyzing effects of climate change and land use and land cover change (LUCC) on biomass accumulation.

\begin{tabular}{|c|c|c|c|c|c|c|}
\hline Groups & Scenarios & LC & fAPAR & Radiation & Temperature & $\mathrm{CO}_{2}$ \\
\hline \multirow[b]{2}{*}{ I } & L1 & $\mathbf{\square}$ & $\square$ & 口 & 口 & $\square$ \\
\hline & L2 & $\mathbf{\square}$ & $\mathbf{\square}$ & $\square$ & $\square$ & $\square$ \\
\hline \multirow{4}{*}{ II } & $\mathrm{C} 1$ & $\square$ & $\square$ & $\boldsymbol{\square}$ & $\square$ & $\square$ \\
\hline & $\mathrm{C} 2$ & $\square$ & 口 & $\square$ & $\mathbf{\square}$ & $\square$ \\
\hline & C3 & $\square$ & $\square$ & $\square$ & $\square$ & $\square$ \\
\hline & $\mathrm{C} 4$ & $\square$ & $\square$ & $\mathbf{\square}$ & $\mathbf{\square}$ & $\mathbf{\square}$ \\
\hline \multirow{4}{*}{ III } & LC1 & $\boldsymbol{\square}$ & $\mathbf{\square}$ & $\boldsymbol{\square}$ & $\mathbf{\square}$ & $\mathbf{\square}$ \\
\hline & LC2 & $\square$ & $\overline{\mathbf{\square}}$ & $\overline{\mathbf{\square}}$ & $\overline{\boldsymbol{\square}}$ & $\overline{\mathbf{\square}}$ \\
\hline & LC3 & $\square$ & $\square$ & $\square$ & $\square$ & $\square$ \\
\hline & LC4 & $\mathbf{\square}$ & $\square$ & $\mathbf{\square}$ & $\boldsymbol{\square}$ & $\mathbf{\square}$ \\
\hline
\end{tabular}

indicates that the input variable changes during 2001-2010, while $\square$ indicates that the parameter value is fixed in the year 2001.

Besides, Group II included four scenarios (C1-C4) to reflect effects of climatic factors (including radiation, temperature and $\mathrm{CO}_{2}$ concentration). Scenarios $\mathrm{C} 1, \mathrm{C} 2$, and $\mathrm{C} 3$ allowed radiation, temperature and $\mathrm{CO}_{2}$ concentration to change, respectively, with the remaining climatic factors, land use types and $F A P A R$ fixed at the level in 2001; Scenario C4 allowed all climatic factors to change, with the land use types and $F A P A R$ were fixed at the level in 2001. In addition, Group III included four scenarios (LC1-LC4) that involved both climate change and LUCC to study their interactive effects on biomass accumulation. Under Scenario LC1, all the input factors were allowed to change during 2001-2010. Scenario LC2 was used to check the interactive effects of water diversion and climate change on biomass accumulation, under which $f A P A R$ and all climatic factors are allowed to change during 2001-2010, and only the land use types were fixed in 2001. Scenario LC3 and Scenario LC4 were used to explore the interactive/non-interactive effects of FVCC and other influencing factors on biomass accumulation, respectively. Under Scenario LC3 only fAPAR was allowed to change over years and all other input parameters were fixed in 2001, while it was on the contrary under Scenario LC4. An additional Scenario for Business as Usual (BAU) was also included, under which all input factors were fixed at the level in 2001, and the effects of influencing factors on biomass accumulation were reflected with the percentage difference of the total biomass accumulation in Group I, II and III relative to that under Scenario BAU.

\section{Results}

\subsection{Model Validation}

There have been a number of studies on biomass accumulation in the Heihe River Basin $[31,56,74,77]$, and the biomass accumulation from the C-Fix model agreed well with that in these studies (Figure 2). For example, the mean annual biomass accumulation the whole study area from the C-Fix model $\left(22.08 \mathrm{gC} \cdot \mathrm{m}^{-2} \cdot \mathrm{a}^{-1}\right)$ was very close to results of Wei et al. (23.51 $\left.\mathrm{gC} \cdot \mathrm{m}^{-2} \cdot \mathrm{a}^{-1}\right)$ [77]. Specifically, the estimated biomass accumulation of cultivated land $\left(157.02 \mathrm{gC} \cdot \mathrm{m}^{-2} \cdot \mathrm{a}^{-1}\right)$ was only slightly lower than the results of Zhang et al. $\left(170.76 \mathrm{gC} \cdot \mathrm{m}^{-2} \cdot \mathrm{a}^{-1}\right)$ and MOD17 $\left(174.57 \mathrm{gC} \cdot \mathrm{m}^{-2} \cdot \mathrm{a}^{-1}\right)$ [74,78]. The biomass accumulation of forestland from the C-Fix model $\left(102.37-178.10 \mathrm{gC} \cdot \mathrm{m}^{-2} \cdot \mathrm{a}^{-1}\right)$ was also consistent with that of Zhang et al. (103.06-187.59 $\left.\mathrm{gC} \cdot \mathrm{m}^{-2} \cdot \mathrm{a}^{-1}\right)$ [74]. The biomass accumulation of grassland from the C-Fix model $\left(95.87 \mathrm{gC} \cdot \mathrm{m}^{-2} \cdot \mathrm{a}^{-1}\right)$ was very close to that in MOD17 $\left(93.01 \mathrm{gC} \cdot \mathrm{m}^{-2} \cdot \mathrm{a}^{-1}\right)$ and Lu et al. $\left(97.73 \mathrm{gC} \cdot \mathrm{m}^{-2} \cdot \mathrm{a}^{-1}\right)$ [56]. The mean annual biomass accumulation of unused land from the C-Fix model $\left(16.77 \mathrm{gC} \cdot \mathrm{m}^{-2} \cdot \mathrm{a}^{-1}\right)$ was only slightly higher than the biomass accumulation of deserts in Zhang et al. (13.61 $\left.\mathrm{gC} \cdot \mathrm{m}^{-2} \cdot \mathrm{a}^{-1}\right)$ [74]. In particular, the mean annual biomass accumulation of swamp from the C-Fix model $\left(80.33 \mathrm{gC} \cdot \mathrm{m}^{-2} \cdot \mathrm{a}^{-1}\right)$ was slightly higher than that in Zhang $\left(74.41 \mathrm{gC} \cdot \mathrm{m}^{-2} \cdot \mathrm{a}^{-1}\right)$ 
and Chen et al. $\left(74.49 \mathrm{gC} \cdot \mathrm{m}^{-2} \cdot \mathrm{a}^{-1}\right)[74,79]$. There are still some differences between the results from the C-Fix model and previous research, which may be due to the difference in the spatial extent of the study area, input data, and parameter values. For example, previous research generally calculated the biomass accumulation in the whole Heihe River Basin, while this study focused on only the lower reach, where the biomass accumulation is relatively lower. Overall, the estimated biomass accumulation from the C-Fix model all fell within the ranges in previous research, indicating that the parameters and algorithm in the C-Fix model are suitable for analyzing the effects of influencing factors on biomass accumulation change in the Low Heihe River Basin.

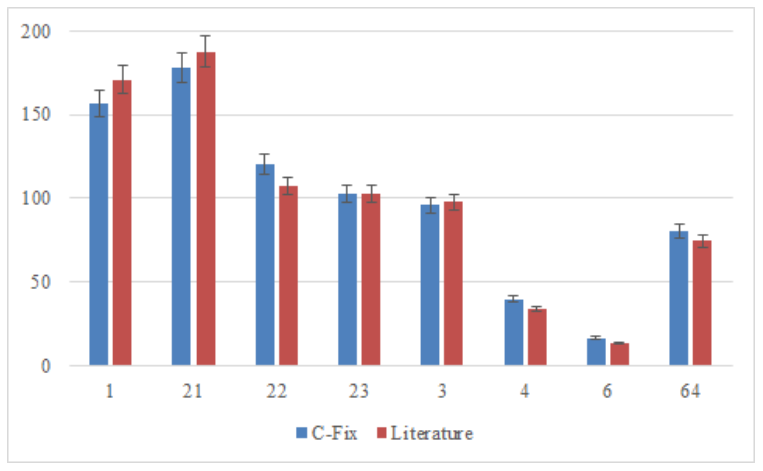

Figure 2. Comparison of mean annual biomass accumulation (Unit: $\mathrm{gC} \cdot \mathrm{m}^{-2} \cdot \mathrm{a}^{-1}$ ) of major land use types from the C-Fix model and the literature $(1,21,22,23,3,4,6,64$ represents cultivated land, closed forest, shrub, open forest, grassland, unused land, and marsh, respectively).

\subsection{Influence of Climate Change and LUCC on Biomass Accumulation}

There was significant climate change in the Lower Heihe River Basin during past decades. According to the meteorological observation data in the Ejina station, the annual total radiation in the Lower Heihe River Basin showed an overall significant declining trend with remarkable interannual fluctuations during 2000-2010 (Figure 3). Besides, as the $\mathrm{CO}_{2}$ concentration of the atmosphere increased year-by-year, the annual mean temperature showed a slight increasing trend in the in the Lower Heihe River Basin during 2000-2010 (Figure 3). In addition, the annual precipitation showed an insignificant increasing trend. Overall, the climate change in the study area was characterized by significant increase of the $\mathrm{CO}_{2}$ concentration and temperature and obvious decrease of the solar radiation during 2000-2010.

LC occurred in $8.19 \%$ of the land in the Lower Heihe River during 2000-2010, most of which occurred between grassland and unused land, and there was only slight change in the total area of different land use types (Figure 4). However, there was considerable change of land use types during the study period in fact. For example, the cultivated land expanded significantly after 2005 as the diverted water increased, the area of which thereafter decreased due to the policy factors, while the grassland changed dramatically, and the area of water bodies increased stably. By comparison, there was more significant change in the fractional vegetation cover, the mean $f A P A R$ of the whole study area ranged between 0.039 and 0.05 , with the extent of variation reaching $14.62 \%$ (Figure 4 ). Besides, there was great difference in the biomass accumulation of different land use types. For example, in 2001 the cultivated land had the highest biomass accumulation $\left(204.67 \mathrm{gC} \cdot \mathrm{m}^{-2} \cdot \mathrm{a}^{-1}\right)$, followed by the forestland $\left(113.96 \mathrm{gC} \cdot \mathrm{m}^{-2} \cdot \mathrm{a}^{-1}\right)$, while the biomass accumulation of grassland and unused land was very low, reaching only 29.44 and $20.84 \mathrm{gC} \cdot \mathrm{m}^{-2} \cdot \mathrm{a}^{-1}$, respectively. However, grassland and unused land accounted for $17.50 \%$ and $69.55 \%$ of the total biomass accumulation of the whole study area due to their large area, while the cultivated land and forestland accounted for only $6.09 \%$ and $5.84 \%$, respectively. 


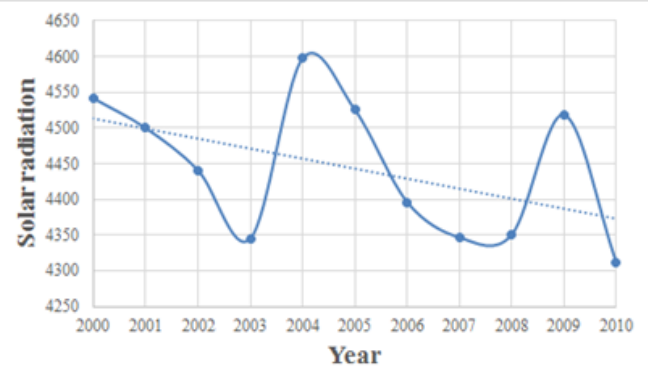

(a)

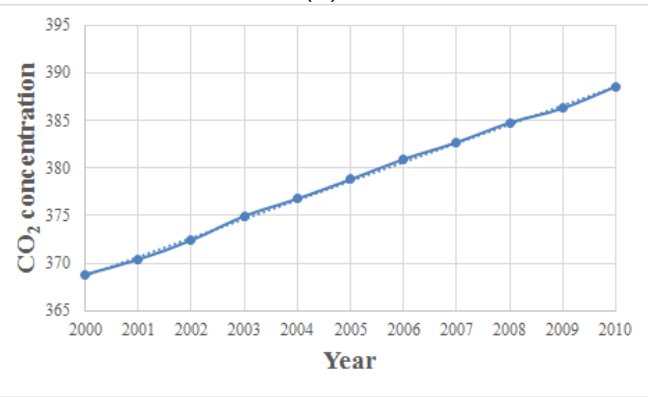

(c)

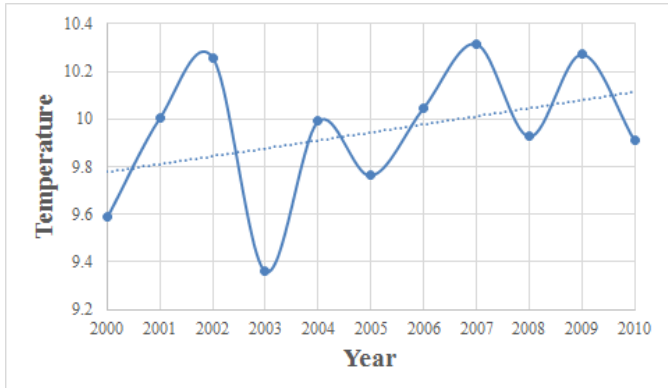

(b)

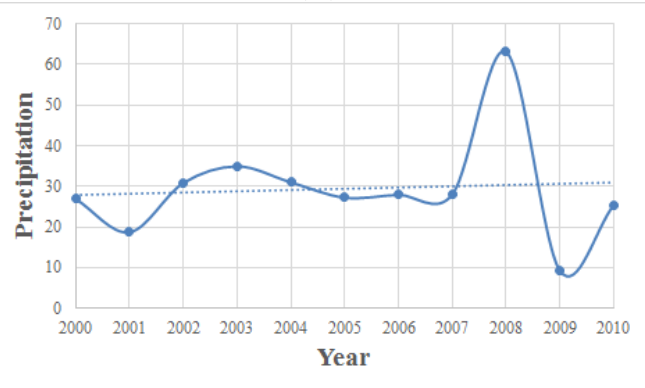

(d)

Figure 3. Changes in climatic factors in the Lower Heihe River Basin during 2000-2010, including (a) the annual total solar radiation (Unit: $\mathrm{MJ} \cdot \mathrm{m}^{-2} \cdot \mathrm{a}^{-1}$ ); (b) annual mean temperature (Unit: ${ }^{\circ} \mathrm{C}$ ); (c) annual mean $\mathrm{CO}_{2}$ concentration (Unit: ppm); and (d) annual total precipitation (Unit: $\mathrm{mm}$ ).

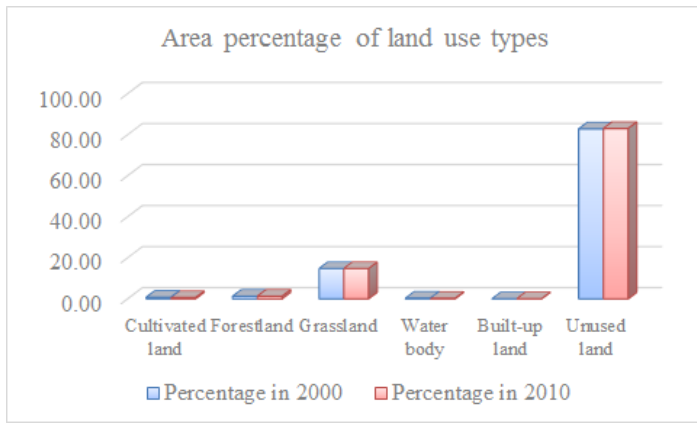

(a)

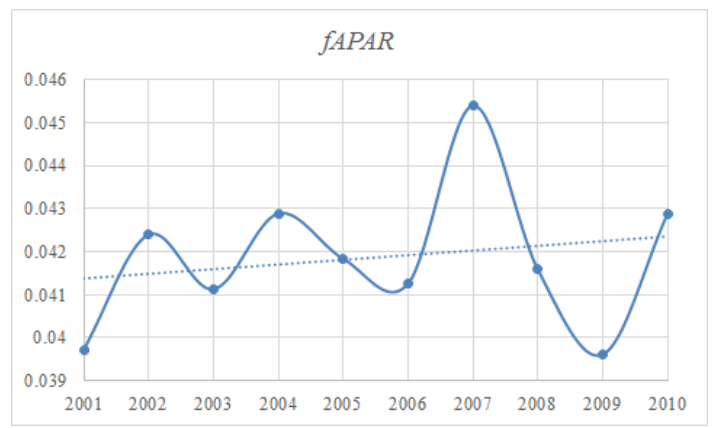

(b)

Figure 4. LUCC in the Lower Heihe River Basin during 2000-2010: (a) area percentage of land use types (Unit: \%) in 2000 and 2010; and (b) annual mean fAPAR of the whole study area during 2001-2010.

Results suggested that there was significant spatial heterogeneity of the annual biomass accumulation in the Lower Heihe River Basin, the spatial pattern of which kept overall unchanged during 2001-2010 (Figure 5). Regions with higher annual biomass accumulation generally concentrated in the oases and regions along the mainstream of the Heihe River, e.g., Ejina Oasis, Yuanyangchi Oasis, and few regions near the Gurinai Lake, while biomass accumulation was generally lower in regions far away from the Heihe River, where the annual biomass accumulation was generally below $50 \mathrm{gC} \cdot \mathrm{m}^{-2} \cdot \mathrm{a}^{-1}$. Besides, the annual total biomass accumulation of the whole study area ranged between 1.58 and $2.09 \mathrm{TgC} \cdot \mathrm{a}^{-1}$, showing an overall increasing trend during 2001-2010, which was consistent with results in previous studies. In addition, results under Scenario LC1, which involved both climate change and LUCC, suggested the total biomass accumulation increased by $0.17 \mathrm{TgC} \cdot \mathrm{a}^{-1}$ relative to Scenario BAU, with an overall increasing rate of 9.78\% during 2001-2010 (Table 3). 


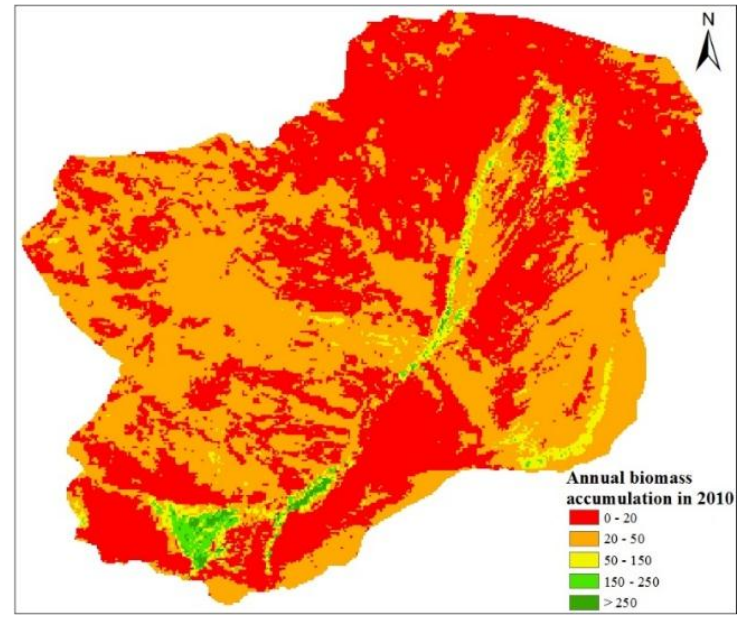

Figure 5. Spatial pattern of the annual biomass accumulation in the Lower Heihe River Basin in 2010.

Table 3. Biomass accumulation changes under different scenarios in the Lower Heihe River Basin during 2001-2010.

\begin{tabular}{cccc}
\hline Scenarios & $\begin{array}{c}\text { Area with Biomass } \\
\text { Accumulation Increase }\end{array}$ & $\begin{array}{c}\text { Area with Biomass } \\
\text { Accumulation Decrease }\end{array}$ & $\begin{array}{c}\text { Overall Biomass } \\
\text { Accumulation Change }\end{array}$ \\
\hline L1 & $1.31 \%$ & $1.80 \%$ & $-1.21 \%$ \\
L2 & $83.16 \%$ & $16.83 \%$ & $70.61 \%$ \\
C1 & $58.91 \%$ & $41.01 \%$ & $-7.37 \%$ \\
C2 & $68.84 \%$ & $31.08 \%$ & $9.89 \%$ \\
C3 & $99.92 \%$ & $0.00 \%$ & $25.55 \%$ \\
C4 & $75.80 \%$ & $24.13 \%$ & $33.45 \%$ \\
LC1 & $90.27 \%$ & $9.72 \%$ & $100.00 \%$ \\
LC2 & $90.37 \%$ & $9.61 \%$ & $99.05 \%$ \\
LC3 & $83.19 \%$ & $16.79 \%$ & $69.76 \%$ \\
LC4 & $75.34 \%$ & $24.58 \%$ & $32.15 \%$ \\
\hline
\end{tabular}

\subsection{Effects of Climate Change on Biomass Accumulation}

Results from Group II showed that there was an overall positive effect of climate change on the total biomass accumulation, accounting for $33.45 \%$ of the total biomass accumulation change, but there was great difference among the effects of climatic factors on biomass accumulation (Table 3 ). The results under Scenarios $\mathrm{C} 1-\mathrm{C} 3$ showed that changes in solar radiation, temperature and $\mathrm{CO}_{2}$ concentration caused $-7.37 \%, 9.89 \%$ and $25.55 \%$ of the total biomass accumulation change, respectively, indicating that the $\mathrm{CO}_{2}$ concentration change was the most important climatic factor that increased the biomass accumulation. Solar radiation and temperature are not the primary controlling factors for interannual variability of biomass accumulation in most models [80], and this study showed that the solar radiation and temperature changes were not the key influencing factors of biomass accumulation change. However, this study showed there was still a rise in photosynthesis and biomass accumulation under elevated temperature, which was also consistent with previous studies [42,74,81]. Moreover, comparison of results under Scenarios $\mathrm{C} 1-\mathrm{C} 4$ indicated that there were some interactive effects of climatic factors, which were mainly due to the $\mathrm{CO}_{2}$ fert amplified by the temperature rise, leading to $5.37 \%$ of the total biomass accumulation change (Table 3 ).

There was obvious spatial heterogeneity in the effects of these climatic factors on biomass accumulation, and the overall positive and negative effects of climate change mainly occurred in the east and west parts of the study area, respectively (Figure 6). Specially, the solar radiation change generally had a negative effect in the west part and a positive effect on biomass accumulation in the east part of the study area, which was especially remarkable in the oases where the fractional 
vegetation cover is high (Scenario C1). Solar radiation is not a limiting factor for vegetation growth in the Lower Heihe River Basin where there is sufficient solar radiation, but the solar radiation change still had very important negative influence on biomass accumulation in the western part of the study area. By contrast, the temperature varied more remarkably and had a more important effect on biomass accumulation. The negative effect of temperature change on biomass accumulation mainly occurred in the regions at a higher altitude, e.g., Mazong Mountain in the west part, while the positive effect of temperature change generally occurred in the plain regions at a lower altitude, especially the oases where the fractional vegetation cover is high (Scenario C2). Results under Scenario C3 showed that increase of $\mathrm{CO}_{2}$ concentration had a positive effect on biomass accumulation in almost the whole study area, which was especially remarkable in regions with high fractional vegetation cover and minor in regions with low fractional vegetation cover, indicating that the influence of $\mathrm{CO}_{2}$ fert on biomass accumulation heavily depends on the vegetation cover and can only directly increase the potential rather than actual biomass accumulation.

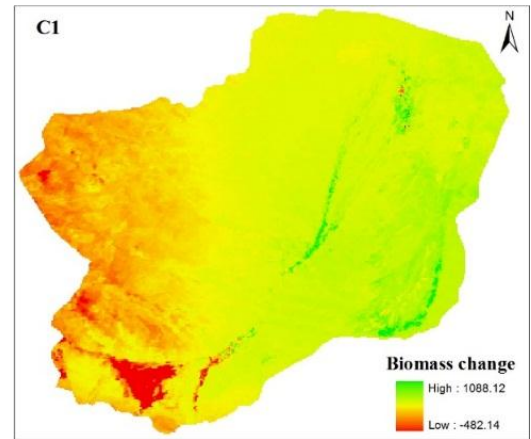

(a)

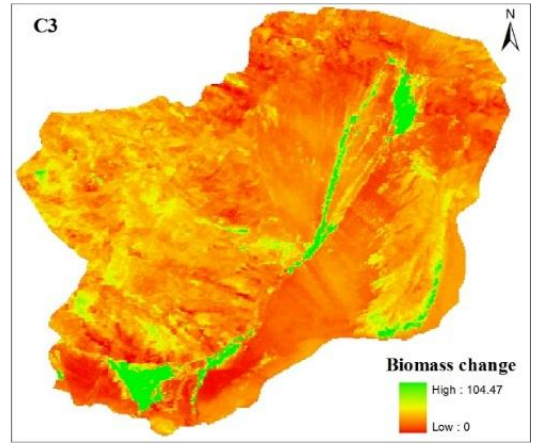

(c)

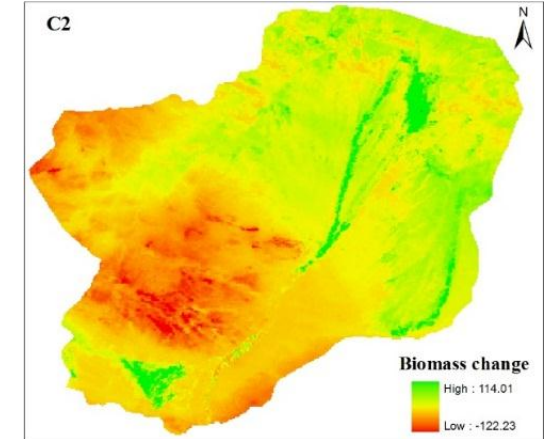

(b)

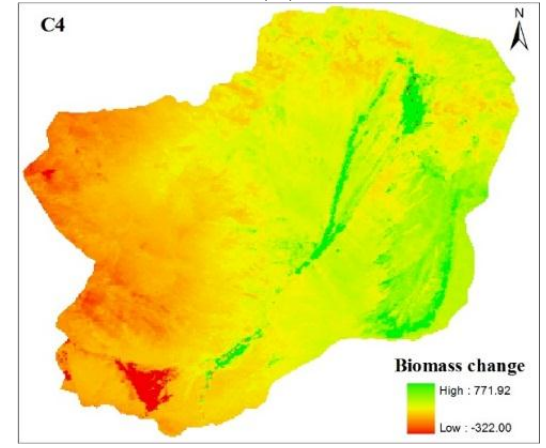

(d)

Figure 6. Spatial patterns of effects of climatic factors on the total biomass accumulation during 2001-2010 in the Lower Heihe River Basin under Scenarios (a) C1 (dynamic solar radiation only); (b) C2 (dynamic temperature only); (c) $\mathrm{C} 3$ (dynamic $\mathrm{CO}_{2}$ concentration only); and (d) $\mathrm{C} 4$ (all climatic factors changing dynamically).

\subsection{Effects of LUCC on Biomass Accumulation}

The results of Group I (Scenarios L1 and L2) suggested there was an overall significant positive effect of LUCC on biomass accumulation change during 2001-2010, and the influence of FVCC on biomass accumulation was more significant than that of LC (Figure 7). Results under Scenario L1 indicated that there was a slight negative effect of LC on biomass accumulation, leading to $-1.21 \%$ of the total biomass accumulation change. Besides, under Scenario L1 the total biomass accumulation generally declined in regions with high vegetation coverage, e.g., Ejina Oasis, regions near the Heihe River to the north of Langxin Mountain, and regions near Gurinai Lake, while it increased in almost the same regions. By comparison, results under Scenario L2 showed that LC and FVCC jointly had an overall significant positive effect on biomass accumulation, accounting for $70.61 \%$ of the total biomass 
accumulation change. In addition, biomass accumulation changed in a wider area under Scenario L2, increasing and decreasing in $83.16 \%$ and $16.83 \%$ of the total area of the study area, respectively (Table 3). Specifically, biomass accumulation increased significantly in the oases and regions along Heihe River, while it decreased significantly in West Juyanhai, Ejina oasis and regions near the Heihe River to the north of Langxin Mountain and a few regions near Gurinai Lake (Figure 7).

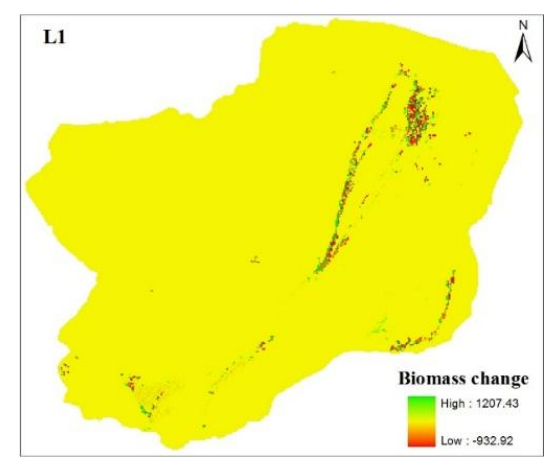

(a)

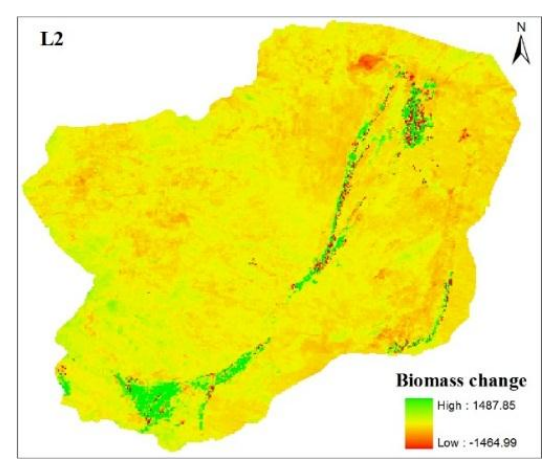

(b)

Figure 7. Spatial pattern of biomass accumulation change under Scenarios (a) L1 (dynamic LC only) and (b) L2 (dynamic LC and FVCC).

\subsection{Joint Effects of Climate Change and LUCC on Biomass Accumulation}

The results under Scenario LC1 showed that there was obvious spatial heterogeneity of the joint effects of climate change and LUCC on biomass accumulation. The total biomass accumulation increased in $90.27 \%$ of the study area under Scenario LC1, most remarkably in the regions with high fractional vegetation cover, e.g., Yuanyangchi Oasis, Dingxin Oasis; while it decreased in $9.72 \%$ of the study area, most remarkably in West Juyanhai, a few part in Ejina Oasis, regions along Heihe River Basin and Yuanyangchi Oasis (Figure 8). Besides, results under Scenario LC3 showed that the FVCC alone made biomass accumulation increase and decrease in $83.19 \%$ and $16.79 \%$ of the study area, respectively, accounting for $69.76 \%$ of the total biomass accumulation change during the study period. The results under Scenario LC4 suggested the joint effects of climate change and LC made biomass accumulation increase and decrease in $69.76 \%$ and $32.15 \%$ of the study area, resulting in an overall increasing rate of $32.15 \%$.

The results from Group III indicated that there were some interactive effects of climate change and LUCC on the total biomass accumulation of the study area (Table 3). The interactive effects of climate change and LUCC on biomass accumulation were integrated into $F A P A R$ representing the FVCC, and results under Scenarios LC1, LC3 and LC4 suggested that the interactive effects of FVCC and other factors (LC and climate change) accounted for $-1.91 \%$ of the total biomass accumulation change. Besides, results under Scenarios C4, LC2 and LC3 indicated that the interactive effect of climate change and FVCC led to $-4.16 \%$ of the total biomass accumulation change, while the results under Scenarios L1, L2 and LC3 indicated the interactive effects of LC and FVCC accounted for 2.06\% of the total biomass accumulation change. The positive effect of LC and FVCC was mainly due to the expansion of forestland during 2000-2010, but it had only minor influence on the total biomass accumulation of the study area since LC occurred in only very few part of the study area (Figure 8). The negative interactive effects of climate change and FVCC had some notable influence on the total biomass accumulation of the study area, which may be due to the influence of climate change on the fractional vegetation cover and total vegetation area through influencing the evapotranspiration and other physiological processes. Overall, although it is challenging to accurately estimate the separate interactive effect of climate change, LC and FVCC, the results still suggested that climate change and LC had a negative and positive interactive effect with FVCC, respectively, which had only slight influence on the total biomass accumulation change. 


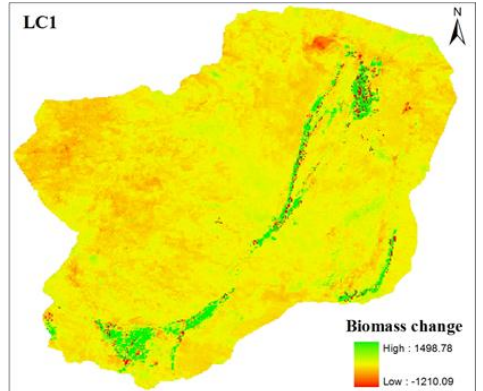

(a)

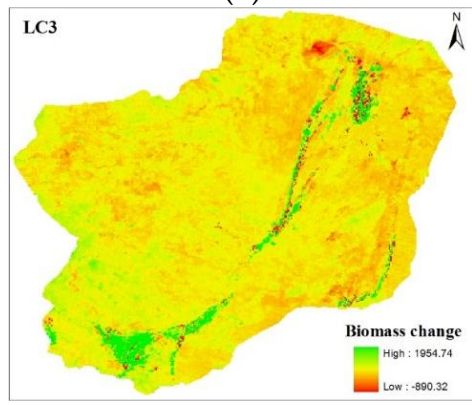

(c)

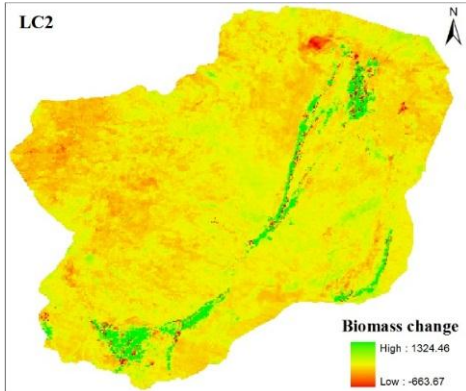

(b)

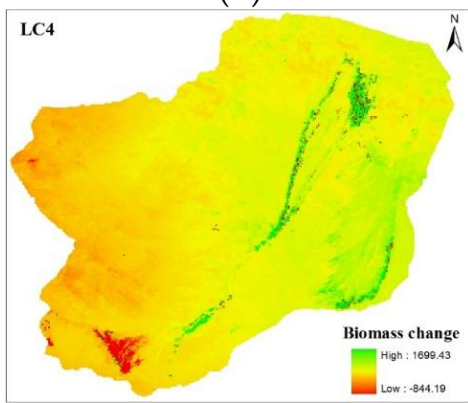

(d)

Figure 8. Spatial patterns of effects of climate change and LUCC on total biomass accumulation during 2001-2010 in the Lower Heihe River Basin under Scenarios (a) LC1 (all factors changing dynamically); (b) LC2 (fixed LC only); (c) LC3 (dynamic fAPAR only); and (d) LC4 (fixed fAPAR only).

\section{Discussion}

\subsection{Model Uncertainties}

The C-Fix model involves key influencing factors of biomass accumulation and the input factors within this model were strictly localized in this study, but there are still large uncertainties in the estimation of biomass accumulation, which may arise from input data, parameters and model structure. First, the accuracy of input data may lead to some uncertainties in the estimated biomass accumulation. For example, the solar radiation data were obtained with data interpolation without consideration of the terrain, which may lead to some bias in the estimated biomass accumulation. Fortunately, plains cover most of the study area, and there is only minor influence of terrain on solar radiation. Besides, determination of parameter values may also lead to some biases in the model output, and there is also some difference in the parameter values between this study and previous research. For example, the radiation use efficiency $\varepsilon$ has been shown to vary between plants, ecosystems and seasons, but in the original C-Fix model a constant light use efficiency is assumed (1.1 gC/MJ), which may be too high for the Lower Heihe River Basin [56]. In particular, $\varepsilon$ is generally assumed to be homogeneous with the grid cells of discrete biome types in most biomass accumulation models, and the $1 \mathrm{~km}$ resolution LUCC data captured the overall trend of land use change but cannot accurately capture the spatial heterogeneity of the seriously fragmented landscapes in the study area, which may cause some biases in the model parameters including $\varepsilon$ and subsequently lead to some uncertainties in the estimated biomass accumulation [76]. To further improve the model performance, it is necessary to determine values of $\varepsilon$ with more observation data and higher resolution LUCC data [17]. Estimation of $f A P A R$ with NDVI tends to overestimate biomass accumulation, this study managed to reduce the consequent errors by adjusting related parameter values, but further adjustment may be needed. In addition, the growing season length is influenced by climatic features and local differences in temperature and energy fluxes [4], but in this study it was set to be constant, which may have slight influence on the estimated biomass accumulation. 
The model algorithms may also contribute to uncertainties in the estimated biomass accumulation and need further improvement. For example, the water limitation has great influence on the vegetation growth and biomass accumulation in the arid and semi-arid regions, but the water limitation is not explicitly modeled in the in C-Fix model, which is only implicitly involved by assimilation of NDVI [82]. A water stress index has been proposed to account for limited photosynthetic activity in case of short-term water stress to improve the C-Fix model $[83,84]$, but more in-depth research is still needed [82]. Besides, there is only a very simplified algorithm of autotrophic respiration in the C-Fix model, which may need to be further improved [60,82]. In addition, the C-Fix model is innovative by involving the $\mathrm{CO}_{2}$ fert, but the model algorithms do not account for some other environmental stresses such as the rooting depth, and more environmental factors may need to be further involved $[15,17,20,85]$. Overall, there are still some uncertainties in estimation of biomass accumulation due to these factors mentioned above, and readjustment of model parameters and more accurate input data may be needed to better estimate biomass accumulation to more accurately evaluate the response of biomass accumulation to environmental factors.

\subsection{Management Implications}

The results in this study suggested there were great differences among the effects of climate change and LUCC on biomass accumulation, which can provide valuable decision support information for adaptive management despite some uncertainties. LUCC is one of the key driving forces of ecosystem services including biomass accumulation, land use management is known to influence the structural canopy development of ecosystems, thereby affecting the net radiation balance and energy partition, and change of vegetation coverage grades was mainly associated with LC at large scales $[7,86,87]$. This study suggested LUCC had an overall positive effect on biomass accumulation in the study area; however, the biomass accumulation change was mainly due to the FVCC rather than LC. FVCC played a dominant role in increasing biomass accumulation, accounting for $69.76 \%$ of the total biomass accumulation change, while LC only had a slight negative effect on the total biomass accumulation. This study also showed there was some interactive effects of LC and FVCC, but with very limited effects on biomass accumulation change, indicating that more attention should be paid to the FVCC in the ecological conservation in this region. However, there are only very few studies that estimated the relative contribution of FVCC or vegetation growth enhancement to biomass accumulation change, while most of previous studies only focused on LC $[1,15,55,77,86,87]$. In particular, the FVCC is more closely related with the water availability in the arid and semi-arid regions at small scales, which dominates the interannual variability of biomass accumulation over large vegetated areas in almost all models [50,80]. However, in most ecological models the water availability is represented with the precipitation rather than the groundwater, the major water source in the arid and semi-arid regions [33,51]. It is therefore necessary to carry out more in-depth research with consideration of the relationship between groundwater resources and FVCC to provide more robust decision support information for ecological management in arid and semi-arid regions [88]. Overall, although humans can influence the capacity of land to produce biomass through land use management, biomass accumulation is still limited by water in the arid and semi-arid regions [27], and more attention should be paid to the FVCC resulting the groundwater table change rather than only LC in the ecological management in these regions such as the Lower Heihe River Basin.

\section{Conclusions}

Assessing the relative contribution of climate change and LUCC to biomass accumulation is critical for planning strategies to mitigate consequent effects. This study estimated biomass accumulation in the Lower Heihe River Basin during 2001-2010 and carried out scenario analysis to investigate effects of climate change and LUCC on biomass accumulation change in a spatially explicit way. Results showed that the joint effects of climate change and LUCC led to a total biomass accumulation increase of $0.17 \mathrm{TgC} \cdot \mathrm{a}^{-1}$, with an increasing rate of $9.78 \%$. There were great differences in effects of 
climate change and LUCC on biomass accumulation. LUCC had a dominant positive effect on biomass accumulation, which was mainly due to the FVCC rather than LC, indicating the FVCC resulting from water diversion played a major role in influencing biomass accumulation and water diversion was effective in increasing terrestrial ecosystem productivity in this region. Climate change showed an overall positive effect on the total biomass accumulation in the study area, which was mainly due to changes of $\mathrm{CO}_{2}$ concentration and temperature. In particular, interactive effects of climate change and FVCC led to slight decrease of the total biomass accumulation.

It is necessary to carry out more in-depth research to improve the estimation of biomass accumulation since there are still some uncertainties due to the model parameters and input data. Nevertheless, the results in this study still revealed the effects of climate change and LUCC on biomass accumulation in the Lower Heihe River Basin, indicating that FVCC resulting from water diversion played a dominant role in influencing biomass accumulation, and more attention should be paid to FVCC rather than LC. In particular, there was obvious spatial heterogeneity in the effects of climate change and LUCC on biomass accumulation, which can provide valuable decision support information for ecological conservation to guarantee the provision of essential ecosystem services in this region.

Acknowledgments: This research was financially supported by the major research plan of the National Natural Science Foundation of China (Grant No. 91325302), and data support from Heihe Plan Science Data Center is also greatly appreciated.

Author Contributions: Haiming Yan made substantial contributions to the data analysis, and drafting and revising the article; Jinyan Zhan made substantial contributions to the concept and design of the article, helped to revise the manuscript, and approved the final version; Feng Wu provided good advice and technical guidance; and Huicai Yang contributed to the manuscript revision.

Conflicts of Interest: The authors declare no conflict of interest.

\section{References}

1. Foley, J.A.; DeFries, R.; Asner, G.P.; Barford, C.; Bonan, G.; Carpenter, S.R.; Chapin, F.S.; Coe, M.T.; Daily, G.C.; Gibbs, H.K. Global consequences of land use. Science 2005, 309, 570-574.

2. Biggs, R.; Schlüter, M.; Biggs, D.; Bohensky, E.L.; BurnSilver, S.; Cundill, G.; Dakos, V.; Daw, T.M.; Evans, L.S.; Kotschy, K. Toward principles for enhancing the resilience of ecosystem services. Annu. Rev. Environ. Resour. 2012, 37, 421-448.

3. Burkhard, B.; Kroll, F.; Nedkov, S.; Müller, F. Mapping ecosystem service supply, demand and budgets. Ecol. Indic. 2012, 21, 17-29.

4. Penttilä, T.; Laurila, T. Carbon dioxide and energy flux measurements in four northern-boreal ecosystems at pallas. Boreal. Environ. Res. 2015, 20, 455-473.

5. Kobayashi, H.; Baldocchi, D.D.; Ryu, Y.; Chen, Q.; Ma, S.; Osuna, J.L.; Ustin, S.L. Modeling energy and carbon fluxes in a heterogeneous oak woodland: A three-dimensional approach. Agric. For. Meteorol. 2012, 152, 83-100.

6. Al-Najjar, M.A.; De Beer, D.; Jørgensen, B.B.; Kühl, M.; Polerecky, L. Conversion and conservation of light energy in a photosynthetic microbial mat ecosystem. ISME J. 2010, 4, 440-449. [PubMed]

7. Chen, S.; Chen, J.; Lin, G.; Zhang, W.; Miao, H.; Wei, L.; Huang, J.; Han, X. Energy balance and partition in Inner Mongolia steppe ecosystems with different land use types. Agric. For. Meteorol. 2009, 149, 1800-1809.

8. Wilhelm, C.; Jakob, T. From photons to biomass and biofuels: Evaluation of different strategies for the improvement of algal biotechnology based on comparative energy balances. Appl. Microbiol. Biot. 2011, 92, 909-919.

9. Nemani, R.R.; Keeling, C.D.; Hashimoto, H.; Jolly, W.M.; Piper, S.C.; Tucker, C.J; Myneni, R.B.; Running, S.W. Climate-driven increases in global terrestrial net primary production from 1982 to 1999 . Science 2003, 300, 1560-1563.

10. Rojstaczer, S.; Sterling, S.M.; Moore, N.J. Human appropriation of photosynthesis products. Science 2001, 294, 2549-2552.

11. Friend, A.D. Terrestrial plant production and climate change. J. Exp. Bot. 2010, 61, 1293-1309. [CrossRef] 
12. Texeira, M.; Oyarzabal, M.; Pineiro, G.; Baeza, S.; Paruelo, J.M. Land cover and precipitation controls over long-term trends in carbon gains in the grassland biome of South America. Ecosphere 2015, 6, 1-21.

13. Yin, X.; Struik, P.C. Constraints to the potential efficiency of converting solar radiation into phytoenergy in annual crops: From leaf biochemistry to canopy physiology and crop ecology. J. Exp. Bot. 2015, 66, 6535-6549.

14. Ferreira, R.A.; de Souza, J.L.; Lyra, G.B.; Escobedo, J.F.; Santos, M.V. Energy conversion efficiency in sugarcane under two row spacings in northeast of Brazil. Rev. Bras. Eng. Agric. Ambient. 2015, 19, 741-747.

15. Caspersen, J.P.; Pacala, S.W.; Jenkins, J.C.; Hurtt, G.C.; Moorcroft, P.R.; Birdsey, R.A. Contributions of land-use history to carbon accumulation in US forests. Science 2000, 290, 1148-1151. [CrossRef] [PubMed]

16. Feldhake, C.M.; Belesky, D. Photosynthetically active radiation use efficiency of dactylis glomerata and schedonorus phoenix along a hardwood tree-induced light gradient. Agrofor. Syst. 2009, 75, 189-196. [CrossRef]

17. Zhang, Y.; Song, C.; Zhang, K.; Cheng, X.; Band, L.E.; Zhang, Q. Effects of land use/land cover and climate changes on terrestrial net primary productivity in the Yangtze River Basin, China, from 2001 to 2010. J. Geophys. Res. Biogeosci. 2014, 119, 1092-1109.

18. Yin, F.; Deng, X.; Jin, Q.; Yuan, Y.; Zhao, C. The impacts of climate change and human activities on grassland productivity in Qinghai province, China. Front. Earth Sci. 2014, 8, 93-103. [CrossRef]

19. Liu, J.; Zang, C.; Tian, S.; Liu, J.; Yang, H.; Jia, S.; You, L.; Liu, B.; Zhang, M. Water conservancy projects in China: Achievements, challenges and way forward. Glob. Environ. Chang. 2013, 23, 633-643. [CrossRef]

20. Pan, S.; Tian, H.; Dangal, S.R.; Ouyang, Z.; Tao, B.; Ren, W.; Lu, C.; Running, S. Modeling and monitoring terrestrial primary production in a changing global environment: Toward a multiscale synthesis of observation and simulation. Adv. Meteorol. 2014, 2014, 1-17. [CrossRef]

21. Tsubo, M.; Walker, S.; Mukhala, E. Comparisons of radiation use efficiency of mono-/inter-cropping systems with different row orientations. Field Crops Res. 2001, 71, 17-29. [CrossRef]

22. Eullaffroy, P.; Frankart, C.; Aziz, A.; Couderchet, M.; Blaise, C. Energy fluxes and driving forces for photosynthesis in lemna minor exposed to herbicides. Aquat. Bot. 2009, 90, 172-178. [CrossRef]

23. Calderini, D.F.; Dreccer, M.F.; Slafer, G.A. Consequences of breeding on biomass, radiation interception and radiation-use efficiency in wheat. Field Crops Res. 1997, 52, 271-281. [CrossRef]

24. Beringer, J.; Chapin, F.S.; Thompson, C.C.; McGuire, A.D. Surface energy exchanges along a tundra-forest transition and feedbacks to climate. Agric. For. Meteorol. 2005, 131, 143-161. [CrossRef]

25. Field, C.B.; Behrenfeld, M.J.; Randerson, J.T.; Falkowski, P. Primary production of the biosphere: Integrating terrestrial and oceanic components. Science 1998, 281, 237-240. [CrossRef] [PubMed]

26. Gingrich, S.; Niedertscheider, M.; Kastner, T.; Haberl, H.; Cosor, G.; Krausmann, F.; Kuemmerle, T.; Müller, D.; Reith-Musel, A.; Jepsen, M.R. Exploring long-term trends in land use change and aboveground human appropriation of net primary production in nine European countries. Land Use Policy 2015, 47, 426-438. [CrossRef]

27. Krausmann, F.; Erb, K.-H.; Gingrich, S.; Haberl, H.; Bondeau, A.; Gaube, V.; Lauk, C.; Plutzar, C.; Searchinger, T.D. Global human appropriation of net primary production doubled in the 20th century. Proc. Natl. Acad. Sci. USA 2013, 110, 10324-10329. [CrossRef] [PubMed]

28. Mu, S.; Zhou, S.; Chen, Y.; Li, J.; Ju, W.; Odeh, I. Assessing the impact of restoration-induced land conversion and management alternatives on net primary productivity in Inner Mongolian grassland, China. Glob. Planet. Chang. 2013, 108, 29-41. [CrossRef]

29. Peng, C.; Apps, M.J. Modelling the response of net primary productivity (NPP) of boreal forest ecosystems to changes in climate and fire disturbance regimes. Ecol. Model. 1999, 122, 175-193. [CrossRef]

30. Huang, K.; Wang, S.; Zhou, L.; Wang, H.; Zhang, J.; Yan, J.; Zhao, L.; Wang, Y.; Shi, P. Impacts of diffuse radiation on light use efficiency across terrestrial ecosystems based on eddy covariance observation in China. PLOS ONE 2014, 9, e110988.

31. Yan, H.; Zhan, J.; Jiang, Q.O.; Yuan, Y.; Li, Z. Multilevel modeling of NPP change and impacts of water resources in the lower Heihe River Basin. Phys. Chem. Earth 2015, 79-82, 29-39. [CrossRef]

32. Ciais, P.; Gervois, S.; Vuichard, N.; Piao, S.; Viovy, N. Effects of land use change and management on the European cropland carbon balance. Glob. Chang. Biol. 2011, 17, 320-338. [CrossRef] 
33. Bai, J.; Chen, X.; Li, L.; Luo, G.; Yu, Q. Quantifying the contributions of agricultural oasis expansion, management practices and climate change to net primary production and evapotranspiration in croplands in arid Northwest China. J. Arid Environ. 2014, 100-101, 31-41. [CrossRef]

34. Yan, H.; Zhan, J.; Liu, B.; Yuan, Y. Model estimation of water use efficiency for soil conservation in the Lower Heihe River Basin, Northwest China during 2000-2008. Sustainability 2014, 6, 6250-6266. [CrossRef]

35. Zhan, J.; Shi, N.; He, S.; Lin, Y. Factors and mechanism driving the land-use conversion in Jiangxi province. J. Geogr. Sci. 2010, 20, 525-539. [CrossRef]

36. Xin, Z.; Xu, J.; Zheng, W. Spatiotemporal variations of vegetation cover on the Chinese Loess Plateau (1981-2006): Impacts of climate changes and human activities. Sci. China Earth. Sci. 2008, 51, 67-78. [CrossRef]

37. Reeves, M.C.; Moreno, A.L.; Bagne, K.E.; Running, S.W. Estimating climate change effects on net primary production of rangelands in the United States. Clim. Chang. 2014, 126, 429-442. [CrossRef]

38. Wu, F.; Deng, X.; Yin, F.; Yuan, Y. Projected changes of grassland productivity along the representative concentration pathways during 2010-2050 in China. Adv. Meteorol. 2013, 2013, 1-9. [CrossRef]

39. Evans, J.; Geerken, R. Discrimination between climate and human-induced dryland degradation. J. Arid Environ. 2004, 57, 535-554. [CrossRef]

40. Deng, X.; Li, Z.; Huang, J.; Shi, Q.; Li, Y. A revisit to the impacts of land use changes on the human wellbeing via altering the ecosystem provisioning services. Adv. Meteorol. 2013, 2013, 1-8. [CrossRef]

41. Song, W.; Deng, X. Effects of urbanization-induced cultivated land loss on ecosystem services in the North China Plain. Energies 2015, 8, 5678-5693. [CrossRef]

42. Rötzer, T.; Liao, Y.; Goergen, K.; Schüler, G.; Pretzsch, H. Modelling the impact of climate change on the productivity and water-use efficiency of a central European beech forest. Clim. Res. 2013, 58, 81-95. [CrossRef]

43. Meng, L.; Chen, Y.; Li, W.; Zhao, R. Fuzzy comprehensive evaluation model for water resources carrying capacity in Tarim River Basin, Xinjiang, China. Chin. Geogr. Sci. 2009, 19, 89-95. [CrossRef]

44. Vörösmarty, C.J.; Douglas, E.M.; Green, P.A.; Revenga, C. Geospatial indicators of emerging water stress: An application to Africa. AMBIO 2005, 34, 230-236. [CrossRef] [PubMed]

45. O'Farrell, P.; Reyers, B.; Le Maitre, D.; Milton, S.; Egoh, B.; Maherry, A.; Colvin, C.; Atkinson, D.; De Lange, W.; Blignaut, J. Multi-functional landscapes in semi arid environments: Implications for biodiversity and ecosystem services. Landsc. Ecol. 2010, 25, 1231-1246. [CrossRef]

46. Ye, Z.; Chen, Y.; Li, W. Ecological water demand of natural vegetation in the lower Tarim River. J. Geogr. Sci. 2010, 20, 261-272. [CrossRef]

47. Tian, Y.; Zheng, Y.; Wu, B.; Wu, X.; Liu, J.; Zheng, C. Modeling surface water-groundwater interaction in arid and semi-arid regions with intensive agriculture. Environ. Model. Softw. 2015, 63, 170-184. [CrossRef]

48. Wang, J.; Cheng, G.; Gao, Y.; Long, A.; Xu, Z.; Li, X.; Chen, H.; Barker, T. Optimal water resource allocation in arid and semi-arid areas. Water Resour. Manag. 2008, 22, 239-258. [CrossRef]

49. Postel, S.L. Entering an era of water scarcity: The challenges ahead. Ecol. Appl. 2000, 10, 941-948. [CrossRef]

50. Earl, H.J.; Davis, R.F. Effect of drought stress on leaf and whole canopy radiation use efficiency and yield of maize. Agron. J. 2003, 95, 688-696. [CrossRef]

51. Herron, N.; Davis, R.; Jones, R. The effects of large-scale afforestation and climate change on water allocation in the Macquarie River Catchment, Nsw, Australia. J. Environ. Manag. 2002, 65, 369-381. [CrossRef]

52. Wang, Z.; Yang, J.; Deng, X.; Lan, X. Optimal water resources allocation under the constraint of land use in the Heihe River Basin of China. Sustainability 2015, 7, 1558-1575. [CrossRef]

53. Deng, X.; Singh, R.; Liu, J.; Güneralp, B. Physical and economic processes of water scarcity and water allocation for integrated river basin management. Phys. Chem. Earth 2015, 79, 1. [CrossRef]

54. Hu, X.; Lu, L.; Li, X.; Wang, J.; Lu, X. Ejin oasis land use and vegetation change between 2000 and 2011: The role of the Ecological Water Diversion Project. Energies 2015, 8, 7040-7057. [CrossRef]

55. Shi, C.; Zhan, J.; Yuan, Y.; Wu, F.; Li, Z. Land use zoning for conserving ecosystem services under the impact of climate change: A case study in the middle reaches of the Heihe River Basin. Adv. Meteorol. 2015, 2015. [CrossRef]

56. Lu, L.; Li, X.; Frank, V. Estimation of net primary productivity of Heihe River Basin using remote sensing. J. Desert Res. 2005, 25, 823-830. 
57. Song, W.; Deng, X.; Liu, B.; Li, Z.; Jin, G. Impacts of grain-for-green and grain-for-blue policies on valued ecosystem services in Shandong Province, China. Adv. Meteorol. 2015, 2015, 1-10. [CrossRef]

58. Wang, Z.; Deng, X.; Li, X.; Zhou, Q.; Yan, H. Impact analysis of government investment on water projects in the arid Gansu Province of China. Phys. Chem. Earth 2015, 79, 54-66. [CrossRef]

59. Kang, E.; Lu, L.; Xu, Z. Vegetation and carbon sequestration and their relation to water resources in an inland river basin of Northwest China. J. Environ. Manag. 2007, 85, 702-710. [CrossRef] [PubMed]

60. Veroustraete, F.; Sabbe, H.; Eerens, H. Estimation of carbon mass fluxes over europe using the C-FIX model and EUROFLUX data. Remote. Sens. Environ. 2002, 83, 376-399. [CrossRef]

61. Jiang, Q.O.; Deng, X.; Zhan, J.; He, S. Estimation of land production and its response to cultivated land conversion in North China Plain. Chin. Geogr. Sci. 2011, 21, 685-694. [CrossRef]

62. Liu, J.; Zhan, J.; Deng, X. Spatio-temporal patterns and driving forces of urban land expansion in China during the economic reform era. AMBIO 2005, 34, 450-455. [CrossRef] [PubMed]

63. Li, X.; Wang, L.; Chen, D.; Yang, K.; Xue, B.; Sun, L. Near-surface air temperature lapse rates in the mainland China during 1962-2011. J. Geophys. Res. Atmos. 2013, 118, 7505-7515. [CrossRef]

64. Trends in atmospheric carbon dioxide. Available online: http://www.esrl.noaa.gov/gmd/ccgg/trends (accessed on 1 October 2015).

65. Wang, K.-Y. Canopy $\mathrm{CO}_{2}$ exchange of scots pine and its seasonal variation after four-year exposure to elevated $\mathrm{CO}_{2}$ and temperature. Agric. For. Meteorol. 1996, 82, 1-27. [CrossRef]

66. Goward, S.N.; Dye, D.G. Evaluating north american net primary productivity with satellite observations. Adv. Space Res. 1987, 7, 165-174. [CrossRef]

67. Deng, X.; Jiang, Q.O.; Zhan, J.; He, S.; Lin, Y. Simulation on the dynamics of forest area changes in Northeast China. J. Geogr. Sci. 2010, 20, 495-509. [CrossRef]

68. Running, S.W.; Thornton, P.E.; Nemani, R.; Glassy, J.M. Global terrestrial gross and net primary productivity from the earth observing system. In Methods in Ecosystem Science; Sala, O.E., Jackson, R.B., Mooney, H.A., Howarth, R.W., Eds.; Springer: New York, NY, USA, 2000; pp. 44-57.

69. Zhu, W.; Pan, Y.; He, H.; Yu, D.; Hu, H. Simulation of maximum light use efficiency for some typical vegetation types in China. Chin. Sci. Bull. 2006, 51, 457-463. [CrossRef]

70. Li, J.; Jie, Z. The Cloud-Free NDVI Data from 2001 to 2011 in the Heihe River Basin; Heihe Plan Science Data Center: Lanzhou, China, 2013.

71. Fensholt, R.; Sandholt, I.; Rasmussen, M.S. Evaluation of Modis Lai, Fapar and the relation between Fapar and NDVI in a semi-arid environment using in situ measurements. Remote Sens. Environ. 2004, 91, 490-507. [CrossRef]

72. Yongming, Y.; Jing, T.; Yuan, R. Monitoring spatial patterns of vegetation phenology in Heihe River Basin based on remote sensing. Remote Sens. Technol. Appl. 2012, 2, 019. (In Chinese)

73. Wang, X.; Ma, M.; Huang, G.; Veroustraete, F.; Zhang, Z.; Song, Y.; Tan, J. Vegetation primary production estimation at maize and alpine meadow over the Heihe River Basin, China. Int. J. Appl. Earth Obs. 2012, 17, 94-101. [CrossRef]

74. Zhang, F.; Feng, Q.; Li, X.; Wei, Y. Remotely-sensed estimation of NPP and its spatial-temporal characteristics in the Heihe River Basin. J. Desert Res. 2014, 34, 1657-1664. (In Chinese)

75. Lazzari, P.; Mattia, G.; Solidoro, C.; Salon, S.; Crise, A.; Zavatarelli, M.; Oddo, P.; Vichi, M. The impacts of climate change and environmental management policies on the trophic regimes in the Mediterranean sea: Scenario analyses. J. Mar. Syst. 2014, 135, 137-149. [CrossRef]

76. Potter, C.S. Terrestrial biomass and the effects of deforestation on the global carbon cycle results from a model of primary production using satellite observations. BioScience 1999, 49, 769-778. [CrossRef]

77. Zhou, W.; Sun, Z.; Li, J.; Gang, C.; Zhang, C. Desertification dynamic and the relative roles of climate change and human activities in desertification in the Heihe River Basin based on NPP. J. Arid Land 2013, 5, 465-479. [CrossRef]

78. Gao, S.; Niu, Z.; Wu, M.; Liu, C. Estimating terrestrial vegetation primary productivity using satellite SAR data. In Proceedings of the 2012 IEEE International Geoscience and Remote Sensing Symposium (IGARSS), Munich, Germany, 22-27 July 2012; pp. 6467-6470.

79. Chen, Z.; Ma, Q.; Wang, J.; Qi, Y.; Li, J.; Huang, C.; Ma, M.; Yang, G.; Yang, G. Estimation of Heihe Basin net primary productivity using the CASA model. J. Nat. Resour. 2008, 23, 263-273. (In Chinese) 
80. Cai, W.; Yuan, W.; Liang, S.; Liu, S.; Dong, W.; Chen, Y.; Liu, D.; Zhang, H. Large differences in terrestrial vegetation production derived from satellite-based light use efficiency models. Remote Sens. 2014, 6, 8945-8965. [CrossRef]

81. Liberloo, M.; Luyssaert, S.; Bellassen, V.; Djomo, S.N.; Lukac, M.; Calfapietra, C.; Janssens, I.A.; Hoosbeek, M.R.; Viovy, N.; Churkina, G.; et al. Bio-energy retains its mitigation potential under elevated $\mathrm{CO}_{2}$. PLOS ONE 2010, 5, e11648. [CrossRef] [PubMed]

82. Verstraeten, W.W.; Veroustraete, F.; Feyen, J. On temperature and water limitation of net ecosystem productivity: implementation in the C-fix model. Ecol. Model. 2006, 199, 4-22. [CrossRef]

83. Moreno, A.; Maselli, F.; Gilabert, M.; Chiesi, M.; Martínez, B.; Seufert, G. Assessment of MODIS imagery to track light-use efficiency in a water-limited Mediterranean pine forest. Remote Sens. Environ. 2012, 123, 359-367. [CrossRef]

84. Maselli, F.; Barbati, A.; Chiesi, M.; Chirici, G.; Corona, P. Use of remotely sensed and Ancillary data for estimating forest gross primary productivity in Italy. Remote Sens. Environ. 2006, 100, 563-575. [CrossRef]

85. Ollinger, S.V.; Aber, J.D.; Reich, P.B.; Freuder, R.J. Interactive effects of nitrogen deposition, tropospheric ozone, elevated $\mathrm{CO}_{2}$ and land use history on the carbon dynamics of northern hardwood forests. Glob. Chang. Biol. 2002, 8, 545-562. [CrossRef]

86. Wu, F.; Zhan, J.; Su, H.; Yan, H.; Ma, E. Scenario-based impact assessment of land use/cover and climate changes on watershed hydrology in Heihe River Basin of Northwest China. Adv. Meteorol. 2014, 2014, 1-11. [CrossRef]

87. Peng, J.; Liu, Y.; Shen, H.; Han, Y.; Pan, Y. Vegetation coverage change and associated driving forces in mountain areas of Northwestern Yunnan, China using RS and GIS. Environ. Monit. Assess. 2012, 184, 4787-4798. [CrossRef] [PubMed]

88. Deng, X.; Zhao, C. Identification of water scarcity and providing solutions for adapting to climate changes in the Heihe River Basin of China. Adv. Meteorol. 2015, 2015. [CrossRef]

(C) 2016 by the authors; licensee MDPI, Basel, Switzerland. This article is an open access article distributed under the terms and conditions of the Creative Commons by Attribution (CC-BY) license (http://creativecommons.org/licenses/by/4.0/). 